\title{
Study on Preparation and Characterization of Value Added Herbal Beverage of Anonla (Emblica officinales Gaertn.) cv. NA-6
}

\author{
Khushbu*, Vijay Bahadur, V.M. Prasad, Saket Mishra and V. Paul \\ Department of Horticulture, SamHigginbottom University of Agriculture Technology and \\ Sciences, Allahabad (U.P.) 211007, India \\ *Corresponding author
}

A B S T R A C T

\begin{tabular}{|l|}
\hline Ke y w or d s \\
Aonla, Cardamom, \\
$\begin{array}{l}\text { Ginger, Tulsi, } \\
\text { Herbal beverage, } \\
\text { Ready-to-serve }\end{array}$ \\
\hline Article Info \\
\hline $\begin{array}{l}\text { Accepted: } \\
\text { 23 August } 2017 \\
\text { Available Online: } \\
\text { 10 September } 2017\end{array}$ \\
\hline
\end{tabular}

A study was carried out on preparation and characterization of value added herbal beverage of aonla (Emblica officinalis Garetn.) cv. NA-6 in Department of Horticulture, Naini School of Agriculture, SHUATS, Allahabad in the year 2016-2017. The experiment was laid out in Complete Randomized Design (CRD) with three replication and nine treatments. The concept was formulation of herbal anola ready-to-serve beverage with three levels of each cardamom, ginger and tulsi as additives. The product was stored in well sterilized glass bottles of $200 \mathrm{ml}$ in post-harvest laboratory at ambient conditions and data was collected from initial day to 90 days on the basis of its physico-chemical properties i.e. TSS $\left({ }^{\circ}\right.$ Brix), Ascorbic acid (mg/100g), Titrable Acidity $(\%), \mathrm{pH}$ and Total sugars (\%). It was found that there was a significant increase in the values of TSS, and pH and total sugar content while acidity and ascorbic acid content of the beverage decreased with time in all the treatments. The shelf life of the product was found to be in good condition upto 90 days.

\section{Introduction}

The importance of fruits in human diets is well recognized due to the presence of rich amount of glucose, fructose, proteins, fats, vitamins, minerals and enzymes to fulfil the demand of balance diet. Due to its rich diversity of agro-climatic and socio-cultural conditions prevailing in the country, India is regarded as Horticultural paradise.

Aonla (Emblica officinalis) occupies an important place among indigenous fruits of India. Aonla belongs to the family Euphorbiacae sub-family-phyllanthoidae. The area under aonla (Indian gooseberry) has been expanding rapidly in the last couple of years.
From about 3,000 ha in the early 80 s the area had stretched to over 25,000 ha in 2000 . It has doubled to 50,000 ha with a production of around 2 lakh metric tonnes in the last two years (Goyal et al., 2008). In the year 201415 , aonla production was $11,73,000 \mathrm{MT}$ and total area under aonla production was 95,000 hectares(National Horticulture Board).

Aonla has a great tolerance to salinity, alkalinity and sodicity. It is a deciduous fruit tree. In this crop flower and fruit set takes place in spring season and soon after the fruits enter dormancy without any growth throughout summer till monsoon. Therefore, 
aonla plants do not require irrigation during summer when most crops would require it. With the onset of monsoon, the fruits start growing and become ready for harvest by December. This is the most ideal crop for arid conditions. A mature aonla tree can tolerate freezing as well as high temperature of $46^{\circ} \mathrm{C}$. Intensive cultivation is being done in the saltaffected districts of Uttar Pradesh including the ravenous area in Agra, Mathura, Etawah, Fatehpur and Semi-arid tracks of Bundelkhand. It is rapidly spreading in the semi-arid regions of Maharashtra, Gujrat, Rajasthan, Andhra Pradesh, Karnataka, Tamil Nadu and the Arawali ranges in Haryana, Kandi area of Punjab and in Himachal Pradesh.

Aonla fruit is used in both Ayurvedic and Unani system of Indian medicines. This fruit is acrid, cooling, refrigerant, diuretic and laxative and useful in anaemia, cough, diarrhoea and jaundice.

The fruit is highly nutritive and is the richest source of vitamin $C(600 \mathrm{mg} / 100 \mathrm{~g})$ among fruits, except Barbados cherry (Asenjoi, 1953) and also have about 20 times more Vit.C than the citrus fruits. The stability of ascorbic acid and astringency in aonla fruit is due to the presence of polyphenols and leucoanthocynins. The fruit has also fair amount of iron, calcium and lysine. However, it is not consumed much as fresh fruit as it is highly acidic and astringent in taste but several value added products like ready-toserve beverage, nectar (Ram, 1984) syrup, jam, murabba, squash, pickles, laddu and candy (Pathak, 1990; Dean, 1992) have been developed from the fruit.

Green cardamom in South Asia is broadly used to treat infections in teeth and gums, to prevent and treat throat troubles, congestion of the lungs and pulmonary tuberculosis, inflammation of eyelids and digestive disorders. It also used to break up kidney stones and gall stones, and was reportedly used as an antidote for both snake and scorpion venom. Cardamom is used as a spice and as an ingredient in traditional medicine in systems of the traditional Chinese medicine in China, Japan, Korea and used in Ayurveda in India. Green cardamom powder is used as a spice for sweet dishes as well as traditional flavoring in coffee and tea (Anand, 1970).

Young ginger rhizomes are juicy and fleshy with a very mild taste. They are often pickled in vinegar or sherry as a snack or just cooked as an ingredient in many dishes. They can also bestrewed in boiling water to make ginger tea, to which honey is often added. Mature ginger rhizomes are fibrous and nearly dry.

The juice from old ginger roots is extremely potent and is often used as a spice in Indian recipes \& Chinese cuisine to flavor dishes. Ginger acts as a useful food preservative and has been proven to kill the harmful bacteria Salmonella (Afshari, 2007).

Basil or tulsi, (Ocimum tenuiflorum or $O$. sanctum) is an aromatic medicinal plant in Lamiaceae family which is native to the Indian subcontinent and widespread as a cultivated plant throughout the South-east Asian tropics. It is cultivated for religious and medicinal purposes, and for its essential oil. It is widely known across the Indian subcontinent as a medicinal plant and an herbal tea, commonly used in Ayurveda and has an important role in Hindu tradition. Tulsi extracts are used in ayurvedic remedies for a variety of ailments. Traditionally, tulsi is taken in many forms: as herbal tea, dried powder, fresh leaf or mixed with ghee. Essential oil extracted from karpoora tulsi is mostly used for medicinal purposes and in herbal cosmetics. 
Beverages based on aonla and ginger and tulsi continues to receive a considerable amount of attention reflecting a growing awareness of the potential of these products in the market place. These beverages have high nutritional quality and increased energy value. These could be particularly useful in place where there is lack of food and improper nutrition leading to deficiencies of certain nutrients (Bakhru, 1998). The development of any process for its economical utilization would be of great benefit to the beverage industry, the development of nutritionally value added product could therapeutically help on improving the health of consumers. Introduction of new types of value added beverages might improve socio-economic status of the country (Singh and Kumar, 1995; Ranganna, 1991).

\section{Materials and Methods}

Fully ripened, mature, fresh and sound aonla fruit were purchased from the orchard of the Department of Horticulture, Sam Higginbottom University Agriculture Technology \& Sciences, Allahabad and the materials such as Potassium Metasulphate (KMS) was sourced from the P.G. laboratory, Deportment of Horticulture, SHUATS, Allahabad. Commercial grade white crystalline cane sugar, good quality readymade cardamom powder, ginger powder and tulsi powder were purchased from the market. After pricking, fruits were dipped in $2 \%$ salt solution for $24 \mathrm{~h}$., then washed with clean water and again dipped in $2 \%$ alum solution for $24 \mathrm{~h}$., further washed with clean water and then boiled for 10-15mins.

Anola fruits were washed in tap water and then seeds were removed. Fruit juice was extracted in a citrus juice extractor. After juice extraction, the juices were kept for 24 hours in refrigerator $\left(4-2^{\circ} \mathrm{C}\right)$ for sedimentation. Then the clear juice was siphoned off and strained through muslin cloth. Herbal (cardamom, ginger and tulsi) extracts were prepared with ratio $1: 1$ powder and water and was heated at $96^{\circ} \mathrm{C}$ for 15 minutes and also filtered through 8-fold cheese cloth. The prepared juice, KMS, and sugar were blended in high speed blender along with the other ingredients as shown in Table. 9 treatment combinations were formulated with herbs (cardamom, ginger and tulsi) and sugar. The details of treatments are depicted in Table. The prepared beverage was kept in $200 \mathrm{ml}$ transparent sterilized glass bottles. Then the samples were cooled with tap water and stored at $4^{\circ} \mathrm{C}$. Treated RTS samples are evaluated at 0, 30, 60 and 90 days for physico-chemical analysis.

The composition of ready to serve herbal aonla beverage was juice- $10 \%$, water- $90 \%$, KMS- $0.3 \%$ and sugar- $15 \%$.

\section{Physico-chemical analysis}

The total soluble solids in the samples were directly recorded by hand refractometer and the results were expressed as per cent soluble solids ( $\left({ }^{\circ} \mathrm{Brix}\right)$ and the values were corrected at $20^{\circ} \mathrm{C}$ with the help of reference table (Ranganna, 2010). pH was measured using and electronic $\mathrm{pH}$ meter. The $\mathrm{pH}$ meter was standardized by using buffers of $\mathrm{pH} 7.00$ and 4.00 prior to recording $\mathrm{pH}$ of the samples.

The ascorbic acid nd acidity was determined as describes by Larmond (Larmond, 1987). Total sugar (\%) was also calculated as described by Ranganna, 2010.

\section{Statistical analysis}

Statistical analysis of data was done by using ANOVA on all experimental groups with three replicates each. The experimental groups were then separated statistically as described by Mukharjee and Sarolia (2002). 


\section{Results and Discussion}

\section{Total soluble solids $\left({ }^{\mathrm{O}} \mathrm{Brix}\right)$}

The data on total soluble solids (TSS) for all the treatments has been presented in Table 2 . A significant increase was found in TSS with increase in storage duration. The effect of treatment on TSS was observed significantly. The lowest mean TSS $\left(14.46^{\circ}\right.$ Brix) was recorded in $\mathrm{T}_{3}$ (1.5\% Cardamom powder) while the highest mean TSS $\left(14.73{ }^{\mathrm{O}}\right.$ Brix $)$ was observed in $\mathrm{T}_{1} \quad(0.5 \%$ Cardamom powder).

The TSS of the beverage increased apparently during storage, which might be due to hydrolysis of polysaccharides in to monosaccharide and oligosaccharides (Bharadwaj and Mukharjee, 2011).

\section{Ascorbic acid (mg/100g)}

Marginal differences in ascorbic acid contents were observed in various treatments. Treated samples also differed from control samples with respect to ascorbic acid content (Table 2).

Statistical analysis showed that the results are highly significant for storage period. Ascorbic acid content decreased significantly at all storage intervals.

The loss of ascorbic acid was attributed to the effect of processing, storage time and exposure to light.

Highest mean ascorbic acid $(23.32 \mathrm{mg} / 100 \mathrm{~g})$ was recorded in $\mathrm{T}_{9}$ (1.5\% Tulsi powder) while the lowest mean ascorbic acid $(21.54 \mathrm{mg} / 100 \mathrm{~g})$ was recorded in control $\mathrm{T}_{0}$ (without herbal powder).

The degradation of ascorbic acid in juice or RTS may follow aerobic and anaerobic pathways. Similar decreasing trend for ascorbic acid contents in different fruit beverage were also reported by Gomez et al., (2005) and Muhammad et al., (1987).

Table.1 Combination of herbs used in value added herbal ready-to-serve aonla beverage

\begin{tabular}{|c|c|c|}
\hline Treatment symbols & Combination of herbs & Detail \\
\hline $\mathrm{T}_{0}$ & Plain product & Without herbal powder \\
\hline $\mathrm{T}_{1}$ & $0.5 \%$ & Cardamom powder (C1) \\
\hline $\mathrm{T}_{2}$ & $1.0 \%$ & Cardamom powder (C2) \\
\hline $\mathrm{T}_{3}$ & $1.5 \%$ & Cardamom powder (C3) \\
\hline $\mathrm{T}_{4}$ & $0.5 \%$ & Ginger powder (G1) \\
\hline $\mathrm{T}_{5}$ & $1.0 \%$ & Ginger powder (G2) \\
\hline $\mathrm{T}_{6}$ & $1.5 \%$ & Ginger powder (G3) \\
\hline $\mathrm{T}_{7}$ & $0.5 \%$ & Basil powder (B1) \\
\hline $\mathrm{T}_{8}$ & $1.0 \%$ & Basil powder (B2) \\
\hline $\mathrm{T}_{9}$ & $1.5 \%$ & Basil powder (B3) \\
\hline
\end{tabular}


Table.2 Effect of treatments on physico-chemical properties (TSS and Ascorbic Acid) of herbal Aonla RTS

\begin{tabular}{|c|c|c|c|c|c|c|c|c|c|c|}
\hline \multirow{3}{*}{ Treatments } & \multicolumn{9}{|c|}{ TSS $\left({ }^{\circ}\right.$ Brix $)$} & \multicolumn{4}{c|}{ Ascorbic acid (m/100g) } \\
\cline { 2 - 12 } & $\begin{array}{c}\text { Initial } \\
\text { day }\end{array}$ & $\begin{array}{c}30 \\
\text { days }\end{array}$ & $\begin{array}{c}60 \\
\text { days }\end{array}$ & $\begin{array}{c}90 \\
\text { days }\end{array}$ & mean & $\begin{array}{c}\text { Initial } \\
\text { day }\end{array}$ & $\begin{array}{c}30 \\
\text { days }\end{array}$ & $\begin{array}{c}60 \text { days } \\
\begin{array}{c}90 \\
\text { days }\end{array}\end{array}$ & mean \\
\hline $\mathrm{T}_{0}$ & 13.05 & 14.09 & 15.04 & 15.76 & 14.48 & 24.91 & 24.00 & 22.00 & 15.25 & 21.54 \\
\hline $\mathrm{T}_{1}$ & 14.09 & 14.04 & 15.04 & 15.75 & 14.73 & 25.11 & 24.20 & 23.40 & 15.45 & 22.04 \\
\hline $\mathrm{T}_{2}$ & 13.06 & 14.06 & 15.03 & 15.74 & 14.47 & 25.31 & 24.40 & 23.20 & 16.05 & 22.24 \\
\hline $\mathrm{T}_{3}$ & 13.05 & 14.06 & 15.01 & 15.72 & 14.46 & 25.11 & 24.20 & 23.50 & 16.25 & 22.27 \\
\hline $\mathrm{T}_{4}$ & 13.09 & 14.04 & 15.03 & 15.74 & 14.48 & 25.21 & 24.30 & 23.40 & 17.25 & 22.54 \\
\hline $\mathrm{T}_{5}$ & 13.09 & 14.06 & 15.03 & 15.74 & 14.48 & 25.31 & 24.40 & 22.80 & 15.45 & 21.99 \\
\hline $\mathrm{T}_{6}$ & 13.05 & 14.09 & 15.04 & 15.75 & 14.48 & 25.11 & 24.20 & 22.60 & 18.75 & 22.67 \\
\hline $\mathrm{T}_{7}$ & 13.06 & 14.04 & 15.04 & 15.75 & 14.47 & 25.21 & 24.30 & 23.50 & 18.95 & 22.99 \\
\hline $\mathrm{T}_{8}$ & 13.09 & 14.06 & 15.02 & 15.73 & 14.48 & 25.29 & 24.40 & 23.80 & 19.25 & 23.19 \\
\hline $\mathrm{T}_{9}$ & 14.00 & 14.06 & 15.04 & 15.75 & 14.71 & 25.31 & 24.40 & 24.00 & 19.55 & 23.32 \\
\hline C.D. at 5\% & 0.114 & 0.010 & 0.004 & 0.013 & & 0.166 & 0.212 & 0.331 & 0.114 & \\
\hline S. Ed. $( \pm)$ & 0.054 & 0.004 & 0.002 & 0.006 & & 0.078 & 0.100 & 0.156 & 0.054 & \\
\hline
\end{tabular}

Table.3 Effect of treatments on physico-chemical properties ( $\mathrm{pH}$ and Acidity) of herbal Aonla RTS

\begin{tabular}{|c|c|c|c|c|c|c|c|c|c|c|}
\hline \multirow{3}{*}{ Treatments } & \multicolumn{9}{|c|}{$\mathrm{pH}$} & \multicolumn{5}{c|}{ Acidity $(\%)$} \\
\cline { 2 - 12 } & $\begin{array}{c}\text { Initial } \\
\text { day }\end{array}$ & $\begin{array}{c}30 \\
\text { days }\end{array}$ & $\begin{array}{c}60 \\
\text { days }\end{array}$ & 90 days & mean & $\begin{array}{c}\text { Initial } \\
\text { day }\end{array}$ & 30 days & $\begin{array}{c}60 \\
\text { days }\end{array}$ & $\begin{array}{c}90 \\
\text { days }\end{array}$ & mean \\
\hline $\mathrm{T}_{0}$ & 3.36 & 3.42 & 3.48 & 4.19 & 3.61 & 0.62 & 0.55 & 0.52 & 0.50 & 0.55 \\
\hline $\mathrm{T}_{1}$ & 3.43 & 3.40 & 3.46 & 4.17 & 3.62 & 0.58 & 0.50 & 0.49 & 0.46 & 0.51 \\
\hline $\mathrm{T}_{2}$ & 3.41 & 3.43 & 3.50 & 4.21 & 3.64 & 0.58 & 0.51 & 0.48 & 0.46 & 0.51 \\
\hline $\mathrm{T}_{3}$ & 3.42 & 3.54 & 3.54 & 4.25 & 3.68 & 0.59 & 0.49 & 0.48 & 0.47 & 0.51 \\
\hline $\mathrm{T}_{4}$ & 3.38 & 3.42 & 3.46 & 4.17 & 3.61 & 0.56 & 0.53 & 0.47 & 0.44 & 0.50 \\
\hline $\mathrm{T}_{5}$ & 3.41 & 3.46 & 3.54 & 4.25 & 3.67 & 0.57 & 0.55 & 0.49 & 0.45 & 0.52 \\
\hline $\mathrm{T}_{6}$ & 3.43 & 3.42 & 3.50 & 4.21 & 3.64 & 0.55 & 0.49 & 0.45 & 0.43 & 0.48 \\
\hline $\mathrm{T}_{7}$ & 3.41 & 3.40 & 3.52 & 4.23 & 3.64 & 0.55 & 0.47 & 0.44 & 0.43 & 0.47 \\
\hline $\mathrm{T}_{8}$ & 3.42 & 3.52 & 3.56 & 4.27 & 3.70 & 0.57 & 0.49 & 0.47 & 0.45 & 0.50 \\
\hline $\mathrm{T}_{9}$ & 3.43 & 3.50 & 3.56 & 4.28 & 3.69 & 0.59 & 0.50 & 0.49 & 0.47 & 0.51 \\
\hline C.D. at 5\% & 0.909 & 0.850 & 0.678 & 0.530 & & 0.047 & 0.543 & 0.524 & 1.153 & \\
\hline S. Ed. $( \pm)$ & 0.429 & 0.401 & 0.320 & 0.250 & & 0.002 & 0.256 & 0.247 & 0.544 & \\
\hline
\end{tabular}

Table.4 Effect of treatments on physico-chemical properties (Total sugars) of herbal Aonla RTS

\begin{tabular}{|c|c|c|c|c|c|}
\hline \multirow{2}{*}{ Treatments } & \multicolumn{5}{|c|}{ Total sugar (\%) } \\
\cline { 2 - 6 } & Initial day & 30 days & 60 days & 90 days & mean \\
\hline $\mathrm{T}_{0}$ & 8.72 & 9.04 & 9.26 & 9.16 & 9.05 \\
\hline $\mathrm{T}_{1}$ & 8.74 & 8.82 & 9.11 & 9.33 & 9.00 \\
\hline $\mathrm{T}_{2}$ & 9.08 & 8.96 & 9.58 & 9.42 & 9.26 \\
\hline $\mathrm{T}_{3}$ & 9.14 & 8.88 & 9.62 & 9.41 & 9.26 \\
\hline $\mathrm{T}_{4}$ & 8.34 & 9.01 & 8.72 & 8.95 & 8.76 \\
\hline $\mathrm{T}_{5}$ & 8.72 & 8.92 & 9.14 & 8.96 & 8.94 \\
\hline $\mathrm{T}_{6}$ & 8.42 & 8.91 & 8.78 & 9.61 & 8.93 \\
\hline $\mathrm{T}_{7}$ & 8.84 & 9.02 & 9.31 & 9.51 & 9.17 \\
\hline $\mathrm{T}_{8}$ & 8.72 & 8.93 & 9.14 & 9.78 & 9.14 \\
\hline $\mathrm{T}_{9}$ & 8.58 & 9.11 & 9.02 & 9.96 & 9.17 \\
\hline C.D. at 5\% & 0.758 & 0.130 & 0.164 & 0.343 & \\
\hline S. Ed. ( \pm ) & 0.357 & 0.061 & 0.078 & 0.162 & \\
\hline
\end{tabular}




\section{Acidity (\%)}

Acidity is also an important attribute because tartness is a major factor in the acceptability of aonla RTS drink. Acid gives the characteristic sourness of the product. Citric acid the major acid in aonla juice that enhances the characteristic flavour of the aonla RTS. The data regarding acidity in different treatments of the product is presented in Table 3. Highest mean acidity $(0.55 \%)$ was recorded in $\mathrm{T}_{0}$ (without herbal powder) while lowest mean acidity $(0.47 \%)$ was recorded in $\mathrm{T}_{7}(0.5 \%$ Basil powder).

There was a gradual decrease in acidity in all the treatments during storage upto 90 days. This might be due to conversion of acids into salts and sugars by enzymes particularly invertase (Kumar et al., 1992). This pattern of decrease in acidity was also reported by Bharadwaj and Mukharjee, (2011) and Deka (2000).

\section{pH}

The $\mathrm{pH}$ has great importance to maintain shelf stability. It can also influence the flavour and processing requirements of the beverage (Table 3). Highest mean $\mathrm{pH}$ (3.70) was recorded in $\mathrm{T}_{8}$ (1.0\% Tulsi powder) while lowest mean $\mathrm{pH}$ (3.61) was recorded in control $\mathrm{T}_{0}$ (without herbal powder).

\section{Total sugars (\%)}

Total sugar of the beverage was observed to be increased gradually upto the end of the experiment in all the treatments under ambient storage conditions which might be due to hydrolysis of polysaccharides in to monosaccharide and oligosaccharides (Bharadwaj and Mukharjee, 2011). Similar result was reported by Garge et al., (2008).data recorded on changes in total sugar (\%) are presented in Table 4. Highest mean
Total sugar $(9.26 \%)$ was recorded in $\mathrm{T}_{2}(1.0 \%$ Cardamom powder) while the lowest mean Total sugar $(8.76 \%)$ was recorded in $\mathrm{T}_{4}(0.5 \%$ Ginger powder).

It can be concluded from this study that herbs can be effectively used as an alternative source of value addition in aonla ready-toserve beverage. On the basis of results obtained, it may be concluded that $\mathrm{T}_{8}(1.0 \%$ Tulsi powder) can be used in commercialization of value added herbal ready-to-serve beverage of aonla. The product remain in acceptable condition even after 90 days of storage.

\section{References}

Afshari, Ali Taghizadeh 2007. "The effect of ginger on diabetic nephropathy, plasma antioxidant capacity and lipid peroxidation in rats". Food Chemistry.

Anand, J.C., 1970. Retention of added vitamin $\mathrm{C}$ in amla preserves. IndFd Pack24: 19-20.

Asenjoi, C. F., 1953. The Story of West Indian Cherry. Boletib del. Collegio-deQuinicosde Pureto Rico, 10: 8-11.

Bakhru, H. K., 1998. Garlic and ginger. Herbs that heal (Natural Remedies for good health) art I: 91-99

Bhardwaj, R.L., and Mukherjee, S. 2011. Effects of fruit juice blending ratios on kinnow juice preservation at ambient storage condition. Afr J Food Sci5: 281286.

Dean, B., 1992. Studies on screening of aonla (Emblica officinalis Garetn.) genotype for processing, M.Sc. (Ag.) Thesis. N. D. University of Agriculture and technology, Faizabad.

Deka, B.C., 2000. Preparation and storage of mixed fruit juice spiced beverage, 2000 Ph.D. Thesis, IARI, New Delhi

Garge, V., Barwal, V. S. and Sarera, S. 2008. Preparation and evaluation of Vitamin 
C enriched fruit drink. Journal of Food Science and technology (Mysore). 45(6): 524-526

Gomez, Saji, and Khurdiya D.S. 2005. Quality changes in aonla pulp under different storage conditions. IndFd Pack59: 54-57.

Goyal, R. K., R.T. Patil, A.R.P. Kingsly, W. Himanshu and K. Pradeep 2008. Status of Post-Harvest Technology of Aonla in India- A Review. Am. J. Food Technol., 3: $13-23 b$

Larmond, E., 1987. Laboratory methods for sensory evaluation of Foods, Deptt of Agri Canada Pub. No. 1637/E.

Muhammad, R., Ahmed, M., Chaudhry, M.A., Hussain, B., and Khan, I. 1987. Ascorbic acid quality retention in orange squashes as related to exposure to light and container type. Pak J Scilnd Res30: 480-483.

Mukherjee, S., and Sarolia, D.K. 2002.
Comparative efficiency of different preservation methods in keeping quality of lime (Citrus aurantifolia) swingle juice during storage. Haryana $J$ HortSci31: 185-188.

Pathak, S., 1990. Post-harvest technology of Aonla (Emblica officinalis Garetn.) Fruit. Ph.D. Thesis, N. D. University of Agriculture and technology, Faizabad.

Ram, B., 1984. Studies on processing and preservation of aonla fruit beverages. Ph.D. Thesis, N. D. University of Agriculture and technology, Faizabad.

Ranganna, S., 2010. Sugar estimation. In: Ranganna, S. (Ed.), Handbook of Analysis and Quality control for Fruits and Vegetables Products, $2^{\text {nd }}$ ed. Tata McGraw-Hill, New Delhi, pp. 12-17

Singh, I.S., and Kumar, S 1995. Studies on processing of aonla fruits: II Aonla Products. ProgsHort27: 39-47.

\section{How to cite this article:}

Khushbu, Vijay Bahadur, V.M. Prasad, Saket Mishra and Paul, V. 2017. Study on Preparation and Characterization of Value Added Herbal Beverage of Anonla (Emblica officinales Gaertn.) cv. NA-6. Int.J.Curr.Microbiol.App.Sci. 6(9): 2373-2379.

doi: https://doi.org/10.20546/ijcmas.2017.609.290 